\section{Aramanday guasu (Rhynchophorus palmarum) como alimento tradicional entre os Guarani Nandéva na aldeia Pirajuí* Aramanday guasu (Rhynchophorus palmarum) como alimento tradicional entre os Guarani Nandéva na aldeia Pirajuí}

\author{
Cajetano Vera** \\ Antonio Brand ${ }^{* * *}$
}

Resumo: Os povos indígenas de modo geral são entomófágicos, os insetos sempre estiveram presentes na suas dietas. $\mathrm{O}$ processo de confinamento dos Guarani em pequenas áreas, como a da aldeia Pirajuí, onde foi realizada a pesquisa, inviabilizou a sustentabilidade no modelo cultural de uso da terra como fonte na produção primária de alimentos. Porém, a utilização de insetos como alimento está presente nesta comunidade. Para avaliar o conhecimento do uso das larvas de besouros como alimento, procurou-se detectar as informações disponíveis através de entrevistas e trabalho de campo na comunidade. Também, utilizou-se substratos de Palmaceae, Acrocomia aculeata (Jacq.) Lodd., para atrair os besouros e identificá-los. Assim foi possível a identificação taxonômica da espécie Rhynchophorus palmarum, conhecido como Aramanday Guasu. Os Guarani de Pirajuí dominam as informações sobre essa importante fonte alimentar.

Palavras-chave: etnoconhecimento, entomofagia, Guarani

Abstract: Indigenous peoples are, in general, entomophagic, since the insects have always been present in their diets. The confinement process of Guarani in small areas, such as the village Pirajuí, where the research was conducted, has prevented the sustainability of the land's use cultural model as a source of food primary production. However, the consumption of insects as food is present in this community. It was accomplished interviews and fieldwork to detect the information available about the beetles, in order to assess the knowledge of the use of beetle larvae as food. Also, it was used Palmaceae substrates, Acrocomia aculeata (Jacq.) Lodd., to attract and identify the beetles
* Esse artigo resulta da pesquisa de mestrado (Vera, 2011) orientada pelo professor Dr. Antonio Brand, de quem fui o último orientando. Antes de partir para um merecido descanso (faleceu em julho de 2012), o desejo desse orientador era de que esse artigo fosse publicado em várias revistas. Ele é meu eterno orientador.

** Mestre em Desenvolvimento Local pela UCDB. Professor de etnociências na Escola Municipal Indígena Tenatui Marangatu de Dourados, MS. E-mail: cajetanoverad@gmail.com *** In memoriam.

\section{Tellus, ano 12, n. 23, p. 97-126, jul./dez. 2012}


Thus it was possible to identify taxonomic species of Rhynchophorus palmarum, known as Aramanday Guasu. The Guarani from Pirajuí dominate the information about that important food source.

Key words: ethnoknowledge, entomophagy, Guarani

\section{Introdução}

Os povos indígenas possuem conhecimentos ${ }^{1}$ sistematizados sobre os insetos, por isso conseguem nomeá-los (Rodrigues, 2005; Cristancho-Sánchez e Barragán-Fonseca, 2011). Segundo Posey (2004), os aborígenes dominam conhecimentos sobre os insetos, pois, assim, os indígenas reconhecem os insetos que lhe servirão de alimentos.

Segundo Costa Neto (2003), quatro insetos principais integram a dieta dos indígenas no Brasil: içá ou tanajura (Atta sp); a larva do bicho-da-taquara (Morpheis smerintha); as larvas de curculionídeos, denominadas de bicho-daspalmeiras (Rhynchophorus palmarum e Rhina barbirostris) e a larva do bicho-dococo (Pachymerus nucleorum).

O médico Coimbra Júnior, em 1984, realizou quatro expedições ao Parque Indígena do Aripuanã, durante quatro anos consecutivos, e chegou à conclusão de que os indígenas Suruí conhecem e dão nomes para insetos comestíveis (Coimbra Jr.; Santos, 1991). O nome é este: kadeg, para larvas que encontravam em árvores conhecidas como babaçu. Essas larvas eram utilizadas fritas, acompanhadas de milho assado e mingau. A gordura era misturada com o urucum e servia para ornamento e fármaco contra várias doenças.

A larva do besouro Rynchophorus palmarum (Linnaeus, 1758) é chamada pelos Suruí mãyõrã. Segundo o autor, os nomes dependem do tipo de árvore em que as larvas são encontradas: quando é encontrado na palmeira, o nome é mãyõrã. Ihbôga é o nome dado à larva quando é encontrada em outros tipos de árvores.

Os Guarani do Brasil possuem profundos conhecimentos sobre os insetos (Noelli, 1993; Rodrigues, 2005) e os utilizam como alimento e como remédio. Segundo Rodrigues (2005) e Badie (2005), os Guarani Mbyá possuem conhecimentos milenares sobre os insetos. Esses autores pesquisaram as abelhas sem ferrões (Hymenoptera, Apidae e Meliponinae) dentro do conhecimento guarani, e os resultados das pesquisas demonstraram que os Guarani conhecem e distinguem 25 etnoespécies organizadas em três categorias diferentes. E ainda conhecem muito bem o ciclo biológico, o habitat, as características

\footnotetext{
${ }^{1} \mathrm{O}$ homem é um ser jogado no mundo, condenado a viver a sua experiência. Por ser existencial, tem que interpretar a si e ao mundo em que vive, atribuindo-lhes significação. Cria intelectualmente representações significativas da realidade. A essas representações chamamos conhecimento (Marques et al., 2008, p. 11).
} 
morfológicas, o manejo, a extração de mel para alimento e remédio e a semidomesticação das abelhas. Porém esses autores não discutiram como a etnia pesquisada classifica os insetos na sua cosmologia.

Segundo Schaden (1974), os Guarani Ñandéva, conhecidos como “Ava Guarani", provavelmente se alimentavam de vários tipos de bichos pequenos e grandes, inclusive dos insetos. As informações mais detalhadas e confirmadas vieram na pesquisa de Rodrigues (2005), as de que as populações guarani conhecem bem a natureza com a qual e interagem. Isso lhes permite uma visão geral sobre os acontecimentos sobrenaturais e naturais, podendo classificar os insetos. O Pe. Franz Müller (1989), na década de 1930, descreveu as variedades de abelhas das quais os Guarani tiravam mel para realizar festa eram muitas.

Melià (2008) e João Izaque (2011) entendem que para os Guarani os alimentos são sagrados, e as larvas dos besouros (mbuku) é um deles. Os alimentos são considerados sagrados, pois estão presentes na natureza como uma dádiva divina. Portanto os Guarani Ñandéva possuem conhecimento específico sobre os insetos comestíveis e não comestíveis, pois, se assim não fosse, não saberiam distinguir entre insetos comestíveis e não comestíveis. O território onde o povo guarani vive é um espaço construído, identificado, vivido ao longo dos séculos.

A alimentação do povo guarani, segundo Schaden (1974), Müller (1989), Braga Neto et al. (2003), Melià (2008) e João Izaque (2011) é culturalmente baseada no milho, mandioca, mel, insetos, pesca e caça de animais grandes e pequenos; comiam moluscos, vertebrados e invertebrados. Para cozinhar, empregavam diferentes técnicas de acordo com a natureza e a combinação dos alimentos utilizados, sendo que as comidas eram assadas, fervidas, torradas, fritas e moqueadas. Segundo Braga Neto et al. (2003), os indígenas Guarani utilizavam vários cultivares, como batata doce, mandioca, amendoim, variedades de frutas, tubérculos, raízes. Ainda se alimentavam de carnes de aves, ovos, peixes etc.

O relatório anual de Nutrição e Dietética da Fundação Nacional de Saúde (FUNASA, 2009) demonstra vários casos de doenças relacionados à desnutrição, subnutrição infantil e geriátrica. Isso ocorre porque as crianças e os velhos não se alimentam adequadamente, ocorre a ingestão de alimentos industrializados inadequadamente como refrigerantes, balas doces, bolachas, carnes enlatadas, massas etc., que contribuem para a má nutrição.

Na aldeia Pirajuí, na divisa entre o Brasil e o Paraguai, entre os índios Guarani Nandéva, há registros de desnutrição (FUNASA, 2005); no entanto, nesta comunidade, ainda preservam entre suas tradições o costume de se alimentarem de insetos (entomofagia), dentre os quais as larvas mbuku guasu de besouros aramanday guasu, cientificamente conhecido como Rhynchophorus palmarum. 
Diante das dificuldades de alimentação dos povos guarani na atualidade, vê-se a necessidade de descobrir e redescobrir na cultura guarani, alternativas de obtenção de recursos alimentares. Conforme Canesqui (2005) e Santos (2011), a utilização de larvas de besouro como alimento pode ser considerada como estratégia de sobrevivência e segurança alimentar.

Existem poucas pesquisas sobre o uso de insetos como alimentos entre os Guarani do Brasil e seus relacionamentos com os insetos, principalmente da ordem Coleóptera. Por esse motivo, este artigo se propõe a estabelecer as bases dessa utilização, como a qualidade e formas de consumo, baseados etnoentomologicamente e antropoentomofagicamente na tradição do indígena Guarani Nandéva. Apresenta como justificativa, além da importância nutritiva, a importância ecológica e a complementação da dieta com o consumo de insetos, em razão de ser um hábito alimentar bem estabelecido e parte da cultura da aldeia Pirajuí.

\section{Terra Indígena Pirajuí}

A aldeia está localizada no município de Paranhos, Mato Grosso do Sul, e tem área total de 2.118, 2325 ha. Fica no extremo sul do estado, na fronteira com o Paraguai, e distante $22 \mathrm{~km}$ da sede municipal. É uma das antigas Reservas Indígenas, que foi homologada e registrada em 1928.

Pirajuí recebia contingentes enormes de indígenas Guarani em trânsito, principalmente nas décadas de 1960 a 1990, período em que não havia outras aldeias em Paranhos. Os Guarani geralmente saíam da região da Grande Dourados para as aldeias Mboi Jagua, Arroio Mokõi, Fortuna Guaçu, Horquetami, Cerro Pytã etc., localizadas no Paraguai. Atualmente Pirajuí recebe menos visitantes, pois, durante o trajeto, há outras opções para se hospedarem, como Arroio Korá, Paraguaçu e Potrero Guaçu.

Na aldeia de Pirajuí os moradores se autodenominam Guarani Nandéva ou Ava Guarani. Cajetano Vera, um dos autores deste artigo, nasceu em 1968, nesta comunidade, onde foi criado, e pertence à família Vera. Lá vivem 472 famílias, no total de 2.133 pessoas, das quais 1.014 mulheres e 1.119 homens (FUNASA, 2010). São 248 as crianças menores de cinco anos de idades do sexo feminino, e 243 as do sexo masculino. Entre cinco e 10 anos, 207 crianças eram do sexo feminino, e 250, do sexo masculino.

Os Guarani de Pirajuí mantêm sua agricultura tradicional de coivara, mas também criam gado, aves, porcos. Os homens saem da comunidade para trabalhar na colheita de maçãs, no sul do Brasil, na usina de cana-deaçúcar e nas fazendas ao redor da comunidade. Na divisão de trabalho entre as famílias, via de regra, as mulheres realizam os trabalhos domésticos, e os homens trabalham na roça. 
Existem cinco nascentes principais e importantes dentro da aldeia, que formam pequenos rios. São as nascentes Kolona'i, Postokue, Cinquenta e quatro e Parcela. Não há rede de esgoto, estação de tratamento de água ou coleta de lixo. Existem dois poços artesianos instalados pela FUNASA, porém o abastecimento de água à comunidade é insuficiente e não conta com tratamento na distribuição de água. A Secretaria Especial de Saúde Indígena (SESAI) distribui à comunidade, por meio do Agente de Saúde, solução de Hipoclorito de Sódio a 2,5\% para purificar a água, mas a comunidade tem dificuldade para utilizá-lo. Os moradores afirmaram que o odor é muito forte, também não faz parte da cultura guarani utilizar substância química para purificar água para usar no dia a dia.

Há duas escolas que atendem as crianças da aldeia. A Escola Municipal "Adriano Pires" fica em Pirajuí, desde 2002. A outra fica fora da comunidade, é a escola "Marechal Cândido Rondon", na Missão Evangélica Unida. Esta é a mais antiga, pois funciona desde 1969. O autor desta pesquisa estudou nessa escola de 1981 a 1985. É professor de Idioma Guarani desde 1989.

Os Guarani que vivem em Pirajuí recebem atendimento de saúde pela SESAI e também pelo Sistema Único de Saúde (SUS). Geralmente os doentes que precisam de internação são encaminhados para o hospital de Paranhos, principalmente as gestantes e doentes com infecções graves. Antes as mulheres indígenas gestantes tinham o parto realizado em casa, assistido por parteiras também indígenas. A gestante guarani começou a ser levada para o hospital para realizar o parto com a instalação da Missão Evangélica Unida, constituída de Missão Protestante compostas de missionários alemães, próxima da aldeia, em 1966. Esse tipo de atendimento intensificou-se com o início de atendimento à saúde indígena pela FUNASA a partir de 2004. Mesmo assim, ainda há procura por medicina tradicional, principalmente por remédios caseiros e por benzimentos realizados por xamãs.

A assistência com cesta básica de alimentação à comunidade iniciou-se em 2003, período em que morreram cinco crianças de Pirajuí na cidade de Dourados, no Hospital da Missão Caiuá. O médico emitiu os atestados de óbitos de que as crianças morreram em consequências de desnutrição. Desde então, as famílias recebem cesta básica do Programa Estadual de Cesta Básica e Fundação Nacional do Índio (FUNAI), uma vez por mês, mas alegam que a cesta básica não é suficiente para passar o mês.

Em geral o Guarani local faz sua refeição três vezes por dia, sem caracterizar o café da manhã como refeição diferenciada. Durante o dia, dá-se preferência à ingestão de carnes, mandioca, arroz, feijão, frutas e variedades de pratos preparados de milho. A prática alimentar diária é bastante diversificada: variedade de milho (Zea mays), mandioca (Manihot esculanta Crantz), batata doce (Ypomoea sp), mamão (Carica papaya), arroz (Oryza sativa), feijões 
(Faseolus vulgaris) e de frutas. Além da banana (Musa paradiasiaca), é lembrada a guavira do campo (Camponesia sp). Esses alimentos são produzidos na comunidade, mas é também grande o consumo de alimento adquiridos no mercado regional, tanto no Brasil como no Paraguai. Por outro lado, para obter os alimentos no mercado, as famílias dependem de recursos financeiros. A aquisição dos alimentos ocorre mais no fim de cada mês, quando recebem os valores em espécies provenientes de aposentadorias, salários ou venda de produtos agrícolas.

Os Guarani Nandéva de Pirajuí recebem os visitantes no pátio da sua casa, oferecem apyka (cadeiras) e tereré, raramente os visitantes são convidados para entrar na casa. Em geral os homens recebem os visitantes homens, e mulheres recebem visitantes mulheres. Esse comportamento também foi percebido entre o Guarani Mbyá pelo pesquisador Arnaldo dos Santos Rodriguês (2005).

\section{Metodologia da pesquisa}

A pesquisa foi realizada de dezembro de 2010 a dezembro de 2011. Para coletar os insetos e classificar, seguindo a visão cosmológica do povo guarani local, foram desenvolvidas atividades em conjunto com a comunidade, incluindo várias turnês guiadas para determinar o local de coleta de insetos, para conhecer tipos de substratos para capturar os besouros e entrevistas.

A primeira atividade realizada para atrair os besouros foi preparar um substrato para que colocassem ovos e, no mesmo substrato, deixou-se crescerem as larvas. Foram utilizados cortes totais e cortes superficiais, aberturas côncavas, no estipe de palmeira mbokaja (Acrocomio aculeata). Esse procedimento já é bem conhecido dos Guarani de Pirajuí, o que na língua guarani é conhecido como mbukuvy.

Para fazer o mbukuvy, foi realizado um passeio guiado, ou turnê guiada, com um cacique rezador (xamã), dois professores, dois adolescentes, duas crianças e o pesquisador. O objetivo bem específico era encontrar o local para o mbukuvy, ou seja, realizar o corte do tronco do Acrocomio aculeata para capturar os besouros e as larvas. Segundo o cacique rezador, deve-se fazer o mbukuvy em um lugar desabitado. Não precisa cortar e derrubar no chão, basta dar um pequeno corte no tronco de palmeira, longe do solo. Se cortar perto do solo, os tatus podem comer as larvas e os besouros. O professor indígena informou que é necessário realizar o mbukuvy entre um conjunto de palmeiras que tenha, ao redor, muitas outras variedades de árvores. Finalmente, foi encontrado o local desabitado, onde havia várias palmeiras e árvores altas e no qual fizemos os mbukuvy. Para essa atividade, o cacique fez ritual do tipo oração e, logo depois, foram cortados quatro pés de palmeiras 
novos. O cacique alega que o Tupã'i cuida das plantas, portanto, precisa de autorização dele para realizar essa atividade.

O cacique descreveu como é feita a "armadilha" para os besouros, ou mbukuvy, que não seja para pesquisa:

Antigamente, quando íamos pescar, caçar e fazer mondéu ou monde [armadilha para pegar tatu, paca, cutia etc.], cortávamos mbokaja ou coqueiro para esse fim. O Tupã Guasu que é o dono da natureza, põe o besouro para comer o resto do mbokaja que não foi usado para armadilha. O mbojaka é alimento para a larva de vários tipos de besouros. $\mathrm{O}$ besouro põe o seu filhote e em 10 semanas estão prontos para comer. Onde há vários pés de mbokaja ou pindó geralmente o vento forte quebra, nesse caso, o Tupã manda o besouro para comer o mbokaja ou pindó que o vento derrubou. Assim a natureza fica melhor na visão do cacique. As casas, antigamente, e ainda hoje, são feitas de madeiras de coqueiros. Para construir a parede da casa, é preciso cortar o pé do coqueiro e, dependendo do tamanho da casa, vários pés. Geralmente aproveita-se a parte mais dura da madeira, e a parte mais mole é deixada para criar a larva de besouro. Assim, nós, do povo guarani lidamos com o besouro e a sua larva. Existem vários tipos de besouros que põem os ovos nas palmeiras para procriar, e o Guarani pode comer todos esses insetos, mas, depende das orientações recebidas por Tupã Guasu. A larva maior o Tupã Guasu² deixou para o Guarani comer. Estas larvas maiores são alimentos puros e fortes.

Atualmente os Guarani de Pirajuí realizam a coleta de larvas de besouros nos locais onde ocorreram cortes de Acrocomio aculeata para construir moradia, roça de coivara, retirada de palmito, abrir pequenas estradas, armadilha e também nos locais onde ocorreram quebras naturais por ventania forte. Os caciques que acompanharam o passeio guiado, afirmaram que natureza cria as larvas dessa forma.

Segundo Setz (1984); Brand (1997); Figueroa (2004) e João Izaque (2011), a população tradicional ou indígena realiza uma interpretação orgânica da natureza para entender o natural e sobrenatural na sua organização social.

\section{Os resultados e discussão}

Para atingir os objetivos, foram estabelecidos parâmetros que permitiram verificar a quantidade, qualidade e disponibilidade de larvas de besouro Rhynchophorus palmarum nas condições da aldeia Pirajuí. Também foram realizadas entrevistas livres e semiestruturadas.

Atualmente, existem 14 caciques na comunidade de Pirajuí, três deles com idade entre 78 a 80 anos, dois entre 52 a 59 anos, um cacique com 39 anos,

\footnotetext{
${ }^{2}$ No mundo ocidental, como Deus todo poderoso.
} 
um cacique 109 anos e três caciques entre 82 a 91 anos. Esses caciques foram entrevistados no primeiro semestre de 2011, e afirmaram que não estão sendo formados novos caciques na comunidade. Portanto esses caciques que detêm os saberes tradicionais na comunidade não estão sendo substituídos.

Um exemplo a ser citado é o dos Kaiowá da aldeia Panambizinho, em Dourados, MS, onde, entre os anos 2003 e 2005, faleceram caciques que eram considerados "livros vivos" por conhecerem bem os saberes tradicionais do povo guarani kaiowá. Na época da pesquisa, a comunidade encontrava-se sem xamãs e os jovens não queriam assumir esse papel importante.

Na aldeia Pirajuí, no segundo semestre de 2011, durante a pesquisa, faleceram dois caciques, um deles foi o senhor Amalho Gonzales, de 89 anos, que colaborou para este estudo.

As entrevistas (21 horas e 12 minutos de gravação), feitas em língua guarani, foram transcritas e digitadas pelo pesquisador. Foram entrevistados 14 caciques rezadores, que representam todos os rezadores da comunidade, oito rezadores do sexo masculino e seis rezadores do sexo feminino. Os caciques detêm domínios de conhecimentos privilegiados dentro da cultura guarani. A inclusão de mulheres é fundamental, porque poderiam deter conhecimento específico sobre o tema, em especial sobre o consumo e preparo dos insetos.

As entrevistas com os caciques foram realizadas em suas próprias residências, com horas marcadas, seguindo o roteiro das perguntas e abordando sempre como o Guarani organiza, utiliza, classifica e percebe os insetos pesquisados, não impondo aos entrevistados qualquer condição para suas respostas.

As entrevistas aconteceram por intermédio de técnicas de entrevistas livres e semiestruturadas. Segundo Amorozo (2002), para essa técnica o pesquisador e o entrevistado mantêm um diálogo livre, sem necessidade de seguir o roteiro previamente estruturado pelo pesquisador. Na entrevista, foi permitido ao entrevistado falar à vontade sobre o uso de larvas e de insetos na alimentação. As pessoas que foram escolhidas para realizar uma turnê guiada com o pesquisador, estas sim, receberam orientações bem específicas sobre a coleta de larvas de besouros que são utilizados como alimento e captura de besouros adultos.

A turnê guiada é um método de pesquisa de campo frequentemente usado por pesquisadores que trabalham com ervateiros e com participantes mais ativos da pesquisa (Mejía, 2002). Nesse processo, o pesquisador poderá fazer entrevistas informais e formais, nas quais se tenta buscar informações sobre nomes de plantas, insetos, répteis etc. $\mathrm{O}$ autor da pesquisa é da comunidade e conhece quem detém mais conhecimento sobre os insetos. Por isso o alvo foram os caciques, os anciãos da comunidade, professores e alunos.

O uso de aramanday ou larvas de besouros como alimento e sua classificação na cultura guarani está diretamente ligado aos saberes que Tupã 
Guasu que deixou para os caciques rezadores utilizarem, como bem ilustra a história contada pela senhora Paula Cabral, de 109 anos, e o senhor Amalho Gonzales, de 89 anos, a seguir. Parte dessa história está registrada por outros estudiosos dos Guarani (Chamorro, 2008, p. 131-141; Silveira, 2011, p. 225-229; Pires e Maciel, 2011).

A origem dos insetos mymba'i kuéra e do aramanday iniciou quando o Tupã Guasu morava aqui na terra. No período em que Tupã Guasu morou na terra, ele foi criando tudo que se vê atualmente. Primeiro ele criou a terra e nesta terra foi criando os seres vivos mymba kuéra. Ele criou a natureza e tudo que nela existe. Ele criou os animais grandes para habitar a terra e a água, pequenos para habitar a terra e a água. Criou mymba ipepova [que tem asas], também mymba'i kuéra [insetos], entre os insetos, está o aramanday guasu. O Tupã Guasu criava os animais e também criava plantas frutíferas para que os animais se alimentassem deles. Ele morou e teve família aqui na terra. No período em que o Tupã Guasu morou aqui na terra, teve como vizinho a Añay. A Añay que é uma figura feminina. A Añay, neste, período não possuía papel específico aqui na terra. $\mathrm{O}$ Tupã Guasu foi homem de roça, plantava bem cedo e no mesmo dia já fazia colheita. O Tupã Guasu se alimentava de milho saboró [Zea mays - Indígena], fruto que ele comeu aqui na terra foi a Guavira e como açúcar, ele comeu mel de jate'i e eirusu. Quando ele morou na terra não comeu carne, mas, comeu o mbuku, a larva de aramanday guasu e aramanday mirĩ e takuara raso. Como o homem ficou zangado com a sua esposa por desobedecê-lo e foi embora para Yvy Marãe' $y$. Quando ele partiu deixou a sua esposa grávida de gêmeos. A mulher, para não ficar sozinha, seguiu o Tupã Guasu com auxílios dos gêmeos ainda no ventre. No caminho, as crianças pediam para que a mãe apanhasse flores de mais variados tipos, mas a infelicidade ocorreu quando ela levou ferroada de uma mamangava, ela ficou brava e bateu na barriga para atingir as crianças, por isso as crianças pararam de conversar com ela. Seguindo a viagem, ela se deparou com a bifurcação de estradas e a mulher esposa do Tupã Guasu seguiu o caminho que a levava para casa do Añay [diabo].

Ela chegou à casa de Añay, representada por senhora velha, logo, foi recepcionada por essa mulher velha, a recebeu com maior sorriso e a alimentou com as frutas silvestres. Os filhos da senhora velha estavam no mato caçando, mas, eles não conseguiram matar nenhum tipo de bichos para comer e retornado para casa, eles descobriram que a velha senhora estava escondendo uma mulher que é a esposa do Tupã Guasu numa panela grande. E eles mataram e a comeram. E tiraram da barriga da mulher dois meninos. Esses dois meninos deram para senhora velha comer. A senhora velha fez várias tentativa para comer as crianças não conseguindo resolveu criar. Esses dois meninos representam na cosmologia guarani o Sol e a Lua. Esses dois meninos tornaram-se bons caçadores e matavam vários tipos de aves, répteis, mamíferos etc., para alimentar a sua dona. Esses dois meninos utilizaram pela primeira vez a 
flecha com os espinhos de mbokaja (Acrocomio aculeata), por isso, mbokaja quer dizer mboka (arma) e ja quer dizer origem, portanto mbokaja quer dizer a origem de armas, principalmente arma de fogo.

Quando os meninos descobriram que a senhora que estavam alimentando era a senhora que comeu a mãe deles, planejaram matá-la. Não conseguindo, então, o Tupã Guasu definiu o papel para a Añay, que elas cuidariam de animais ferozes, peçonhentos e insetos ruins (ivaiva). E, pediu aos seus filhos para preparar a terra de tal modo que os descendentes do Tupã Guasu que vão habitar a terra não venham a passar fome, então, revigoram vários tipos de plantas frutíferas, entre as plantas frutíferas, estão as variedades de Acrocomio. Deixou variedades de animais que serviriam para o povo guarani comer, entre as variedades de animais, está o Aramanday Guasu e Aramanday mirĩ. Quando os filhos de Tupã Guasu foram embora para a Terra Sem Mal [Yvy Marãe'y], o Tupã Guasu criou um cacique Yvyra'ija para cuidar da natureza.

Assim é o mito sobre a origem de animais e do aramanday. O cacique que recebeu as orientações do Tupã Guasu é o Deus responsável por ensinar e demonstrar os alimentos para as crianças, jovens e adultos. Esse cacique dirá ao povo guarani o que comer e terá que abençoar os alimentos antes de consumir. Os alimentos considerados inadequados para o Guarani, um cacique reconhece e reprova o uso. Os alimentos reprovados são destinados a Añay comer e o Guarani Ñandéva não pode comer.

Tupã Guasu criou tudo para que o Guarani, que é o descendente direto do Tupã Guasu, não venha passar necessidade. Ele criou os animais pequenos e grandes, criou as aves pequenas e grandes, criou as plantas de todos os tipos, criou a água e deixou seus filhos Kuarahy (Sol) e Jasy (Lua) para cuidarem de tudo que criou.

\section{A classificação guarani dos insetos}

A palavra mymba em geral é mais usada por caciques. Para os caciques rezadores, todos os animais são $m y m b a$, pois pertencem ao Tupã Guasu. Por isso os animais são criaturas sagradas para o povo guarani. Os insetos perigosos são aqueles insetos destinados a Añay e todos os demais pertencem ao Tupã Guasu. Quando o Tupã Guasu definiu o papel de Añay, também foi definido o relacionamento entre a Añay e o povo guarani. Na cosmovisão guarani, a palavra Añay, significa indivíduo perigoso, mau, trapaceiro etc. Os dois grupos de animais, mymba que pertencem ao Tupã Guasu e à Añay, inclusive os insetos, são bem distintos. Esses dois grupos de insetos são importantes nos conhecimentos do povo guarani. Os que pertencem ao Tupã Guasu são animais e insetos úteis à natureza e ao ser humano. 
Os Guarani da aldeia Pirajuí classificam os insetos obedecendo aos saberes recebidos de Tupã Guasu e também através das experiências no dia a dia. Os professores Pedro Duran, de 42 anos, e Jonathas Duran, de 38 anos, afirmam o seguinte sobre o conhecimento dos insetos: "Ore roikuaa vicho' $i$ kuéra, ore ru ha ore sy ohechauka ha ore rekombo'e va'ekue oreve". Eles conhecem os insetos, porque os pais lhes ensinaram no dia a dia. Os caciques que foram entrevistados declaram: "Ore rojerokýva roikuaa vicho'i kuéra, Tupã Guasu voi ore rekombo'e". Eles afirmam que conhecem os insetos, pois receberam os ensinamentos direto da Divindade. Os Ava Guarani, quando falam sobre esses saberes, utilizam as expressões tekombo'e e hechauka. A expressão "tekombo'e" significa ensinar para que o indivíduo aprenda para o resto da vida. A expressão "hechauka" significa ensinar com demonstrações, pois, não basta só dizer, precisa mostrar o que está sendo ensinado. Para Melià (2008) e Chamorro (2008), essas expressões são utilizadas como uma estratégia de ensino e aprendizagem.

Para classificar utilizam a terminologia no'ó, é usado por Guarani local, para indicar o grupo de insetos. A expressão mbuku quer dizer todas as variedades de larvas que são reconhecidas como alimento. A expressão yso quer dizer todas as variedades de larvas que não são reconhecidas como alimento. O senhor Amalho Gonzales e dona Paula Cabral, que são Yvyra'ija (especialistas), no conhecimento sobre os animais e insetos, descreveram os conhecimentos revelados por Tupã Guasu em sonhos:

Fomos inseridos por Tupã Guasu em campo muito grande e em um mato bem fechado, ele colocou diante de nós todos os tipos de animais. E disse: escolhi vocês para cuidar dos animais pequenos e grandes. Nós dissemos para ele que vamos cuidar dos insetos. Então, ele nos ensinou todas as particularidades sobre os insetos: habitat, reprodução, as características biológicas, hábito alimentar, a locomoção etc. Há variedades de insetos de tamanho e cores. Os grupos destes insetos possuem características próprias de cada grupo; há insetos que não possuem ossos, porém, possuem músculos que lhe ajudam andar e pular, há espécies que voam e com hábito diurno e noturno. As espécies que se alimentam especificamente de plantas e outros se alimentam de outros insetos. Ordens do Tupã Guasu é que podemos comer insetos que possuem cores brancas, com cores verdes e com cores avermelhadas. Verifique os grupos de insetos: Aramanday no'õ [Coleoptera], cujo adulto põe larvas comestíveis, Eirusu'õ [grupo das abelhas], Japeusa no'ó [Aracnideo], Kava'ó [Hymnoptera], Kupi'i no'ô [Isoptera], Kyju'õ [Orthodoptera], Ky no'ó [Phthiraptera], Mberu no'ó [Diptera], Mboisy no'õ [Julifornia], Ñakyra'ó [Homoptera], Nahati no'ó [Odonata], Lembu'ó [Coleoptera do grupo não comestíveis], Tahýi no'ô [Hymnoptera], Tu no'ó [Anoplura], Tungusu no'ó [Siphonpetra] Panambi no'ó [Lepidoptera], Tuku no'ô [Acriinideo] e Tarave'ô [Blattodeae]. Esses são grupos de insetos que o Tupã Guasu demonstrou para mim e para o senhor Amalho. 
Pode-se perceber que o ponto referencial para a classificação dos insetos é a natureza intacta, $k a^{\prime}$ aguy. Durante a entrevista, afirmaram que eles receberam orientações de Tupã Guasu dentro de um mato fechado e campo cheio de insetos. A classificação dos insetos na cosmovisão dos caciques entrevistados ocorre mediante as características externas e internas, cores e tamanhos, os hábitos alimentares, o comportamento, o local onde vivem, a reprodução, o perigo que apresenta para o ser humano e as outras espécies, e ser Tupã rymba (ver Lista 2) ou Añay rymba (ver Lista 1).

O nome de cada grupo de insetos é revelado por Tupã Guasu para os caciques em sonhos. Em cada grupo de insetos, é usada a terminação no'õ. O aramanday possui estas características externas, segundo o cacique Norberto Cabral, de 58 anos:

Mbuku mirĩ, estes existem três classes: o primeiro, de cor tudo preta, é igual aramanday guasu, hábito diurno, voa durante o dia, possui rosto, as patas dianteiras e traseiras são fortes para cavar, se alimenta de seiva das plantas. O segundo aramanday mirĩ é colorido, listrado: cor preta e vermelha. Ou seja, listras avermelhadas na região dorsal e pretas na região ventral. O terceiro, também colorido, listras coloridas, preta na região ventral e listra cor amarelada na região dorsal.

O cacique precisa reconhecer o local onde e como vivem as larvas (mymba'i kuéra), assim, é possível saber o período certo e a quantidade para coleta, como também diferenciar entre os insetos ruins e perigosos dos insetos considerados úteis. Na cosmologia, o cacique, o Yvyra'ija, precisa reconhecer o poder (mbarete) que vem de Añay e de Tupã Guasu, assim é possível dialogar com os poderes da divindade para que as pragas ou doenças não prejudiquem um determinado lugar e consequentemente atinjam o povo guarani.

É necessário reconhecer as características do inseto, pois, em se tratando de alimento, favorece a escolha do estágio mais apropriado para o consumo. Em caso do uso do mbuku, os caciques sabem que devem passar 42 dias após cortar o pé de palmeira para realizar as coletas.

Os caciques precisam conhecer os aspectos reprodutivos para saber se os insetos põem ovos, saber as quantidades exatas dos ovos e reconhecer a fêmea e o macho. O aramanday guasu põe o mbuku guasu (larva grande). Suas características externas são possuir mokõi po ha irundy py (o par de mãos dianteiras e quatro pernas traseiras) e o macho ser maior do que a fêmea. Existem três espécies aramanday mirĩ ou aramanday'i: totalmente cor negra (hũmbaite), colorido (iparapa) e de cor vermelha quase preto (pytãngy).

O hábito alimentar do mymba'i kuéra é importante reconhecer, pois assim o cacique irá reconhecer em que planta procurar ou identificar as plantas que são hospedeiras dos insetos comestíveis. O aramanday alimenta-se de orvalho, possui hábito diurno, durante o inverno se esconde nas galerias das árvores. 
É totalmente negro (hũmbaite). Entre agosto a abril é o período propício para encontrar o besouro adulto, quando está calor. O indígena local usa a expressão criar: para criar precisa cortar o coqueiro ou a palmeira, tirar o palmito e deixar por dez dias para iniciar a infestação.

\section{Os insetos Añay rymba}

Durante o passeio guiado, os caciques rezadores afirmaram e demonstraram os insetos existentes na aldeia, também a classificação, segundo a cosmologia guarani. O autor deste projeto procurou aproximar os nomes científicos da língua guarani para língua portuguesa. A lista dos insetos abaixo não segue a lógica de taxonomia ocidental. Ela foi construída pelo autor durante a pesquisa.

LISTA 1 - Añay Rymba - Mymba ou Vicho'i kuéra (Etnoespécies)

ARACNÍDEO

ESCORPIÕES: Japeusa no'ó

JAPEUSA - Bothrisurus vittatus.

JAPEUSA - Escorpiões.

NANDU - Aranhas. Nome geral das ficnídeas.

NANDUPE - Aranhas chatas.

NANDU- KAVAJU - Sub-origem mygalomorphus.

NANDUTÍ - Tecido fino de linha ou seda feito a mão, como teia de aranha.

ÑANDU-INIMBO - Teia de aranha.

\section{ÁCAROS- ISOXÍDEO}

JATEVU - Carrapato, Boophilus microplus (de gado); Ixodes reduvius (do cão); Ixodes loricus (do gambá).

\section{Ordem Anoplura: Tũ no' $\tilde{\boldsymbol{o}}$}

$T \tilde{U}$ - Bicho de pé, Sarcopsylla penetrans (Tunga penetrans)

\section{Ordem Blattodea - Tarave no' $\tilde{\boldsymbol{o}}$}

TARAVE KARU- Barata. Blatídeos. Baratas devoradoras de alimentos dentro de casa. 


\section{Ordem Diptera: Mberu no' $\tilde{o}$}

MBERU - Moscas; mosca comum.

MBERU HOVY - Mosca verde; Sacophaga carnarias; Saconexia chlorogastes: da carne.

MBERU ÑANRÕ - Stomix calcitrans.

MBUTU - Tavão. Brachyceros. Tabanídeo.

$\tilde{N} A T \tilde{I}^{\prime} \tilde{U}$ - Mosquito. Culicídeo.

NATI'U MBA'ASY JÁRA - Aedes aegipti, Culex quinquefesciatus,

ÑATI'Ũ AKUÁ - Mosquitos. Anophelinos.

NATII'Ũ KARÃPÁ - Mosquitos. Culicídeos

NATI'U PEPO MOROTI - Mosquito do grupo Lutzomyia

MBARIGUI - Mosquitos pólvora, nome comum aos miruim simúlidos (polvorim chiromídeos). Maruim.

MBIGUÍ - (polvorím). Chironomus ssp.(Birigui; tatuquira).

KARACHÃ - Gênero Flebotomo.

URA - Larva mosca, berne, miase cutânea.

ÚRA, YSO, YSO KARU - São nomes de lagartas (Lepidoptera)

\section{Ordem Homoptera - Ñakyrã no' $\tilde{o}$}

TAMBEJU'A - (CHICHÃ: espanhol), percevejo. Acanthis lectularia.

TAMBEJU'A - Especialmente os percevejos grandes.

TAMBEJU'A KA'AGUÝ - Gênero Edesa.

TAMBEJU'A GUASU - Reduvídeos: triatomas e outras variedades. Barbeiros, percevejos de mato.

\section{Ordem Hymenoptera - Tahýi no' ó}

TAHÝI TATA - Eciton vagans, especialidade de TAHÝIRE.

GUAIKURU - Formiga caçadora, eciton crassiocorne (rouba os ovos das outras).

TAHÝI JAGUARETE - Multilidae

\section{Ordem Hymenoptera: Kava no' $\tilde{o}$}

KAVA - Marimbondos e vespas.

KAVA HŨ - Vespa preta

KAVA PYTÃ - Gênero polistes: KAVYTÃ. (Cabapitá: cabapiranga).

KAVA SAYJU - Vespa amarela 
KAVICHU'I - Pequena vespa escura.

KAVA TATU - Synoeca cyanea FABR., 1775

KAVA LECHEGUANA - Brachyhastra lecheguana (LATR., 1824)

$K A V U$ - Pequena vespa.

KAMUATÍ - Vespas pequenas, escuras. Polybia scutellaris. Camoatim: abelhas pretas em beiras de casas e janelas.

LECHIGUANA - Vespas sociais. Nectaria maglia e n.lechiguana.

LECHIGUANA PYTÃ - Vespas muito irritáveis, chartegus brasilliensis.

SAÑARO - Nome comum para abelhas solitárias verdes e azuis. Andrenídae.

MAMANGA - Besouro. Var. Gênero bombus, xylocoda e cintris.

\section{Ordem Lepidoptera - Panambi kure no' õ}

MARANDOVA - Gusanos, larvas de mariposas, gordas, sem pelos; larvas de Lepidoptero; traças, curuquerê.

YSO TATURÃ - Larvas com lã ou pelos urticantes, de Megalopyga lanata e espécies afins de Lepidóptero.

YSO KARU - A larva ou gusano; lagarta devoradora de folhas de plantas. YSO JAGUA - Larvas de insetos, sem pelos; com extremidade cefálica; engrossada, com manchas no corpo.

YSO TATA - Larvas luminosas de insetos.

\section{Ordem Juliformia}

$A M B U^{\prime} A$ - Nome comum a todos. Nome científico de Embuá: Lulus sabulosus cllindroiulus

Centopia - Mboi chagua Centopeia (Scolopendra gigantea robusta)

\section{Ordem Odonata - Ñahati no' $\tilde{o}$}

$\tilde{N} A T I ' U$ - variedades de pernilongos

\section{Ordem Phthiraptera - Ky no' $\tilde{o}$}

Os piolhos do homem e dos animais.

KYPE - Ptirius inguinalis; chato.

$K Y-$ Pediculus capitis; piolho.

$\tilde{N} A M O K Y R \tilde{A}$ - P. vestimenta; piolho de roupa. Muquirana.

$\tilde{N} A M O K Y R \tilde{A}-R A^{\prime} Y$ - Lêndea do ÑAMOKYRÃ.

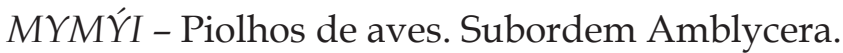




\section{SARCOPTÍDEO}

MYMÝI - Dermanicus.

KURA' $\tilde{Y} I, K U R U$ - Sarna sarcoptes scabiei, var. horminis.

PIRA - Sarna de animais domésticos.

\section{Ordem Siphonaptera}

TUNGUSU - Pulga, Pulex irritans, Tunga penetrans.

\section{TETRÓXIDO}

KUI'I - Bicho vermelho, Tetronichus molestissimus; (existe também um KŨI'Ĩ que é roedor. Cocudu villosus). Micuim.

Segundo João (2011), para os Guarani Kaiowá as pragas que estão presentes na lavoura são atribuídas ao espírito do $P a^{\prime} i$ Tambeju. Na cosmologia dos Guarani Kaiowá, o $P a^{\prime} i$ Tambeju, no início da criação, foi designado para cuidar da lavoura, mas ele errou diante do Tupã Guasu, cometeu ato de fornicação com a irmã do Tupã Guasu. Por isso, o Tupã Guasu o castigou com uma doença que lhe custou a vida. $\mathrm{O}$ ato de fornicação dele com a irmã do Tupã Guasu resultou no nascimento de um menino. Quando o Pa'i Tambeju estava para falecer, chamou o filho e lhe deu ordem para que cuidasse das plantas, porém ele recusou o mandamento do pai.

Os caciques Guarani Ñandéva entrevistados para esta pesquisa não falam do $P a^{\prime} i$ Tambeju, mas eles falam que na criação o Tupã Guasu designou a natureza sob os cuidados de Añay, pois, nesse período, não havia o Guarani na face da terra. Quando o Tupã Guasu foi para Yvy Marãe'y, colocou o Guarani na face da terra e tirou da Añay várias espécies de animais e plantas para servir de alimentos para o povo Guarani Nandéva. Os animais que o Tupã Guasu retirou do domínio da Anãy ficaram sob seus cuidados e os demais ficaram sob o domínio do Añay até o presente momento.

\section{Os insetos Tupã Guasu rymba}

\section{LISTA 2 - Tupã Guasu Rymba}

Ordem Blattodeae -Tarave no' ó

TARAVE - Baratas. Blatideos.

\section{CRUSTÁCEOS}

JAPEUSA - Caranguejos.

TUKU - Lagostas.

POTI - Camarões. 
Ordem Coleoptera - lembu no' $\tilde{o}$

ARAMANDAY - Rinchophorus palmarum, Metamasius sp, Cosmopolite sp $L E M B U$ - Escaravelho, lamelicórnios.

MUÃ - Vagalumes.

TIGUÃ' Ã, KIMBU- Gorgulhos e geral, calandra gramaria.

YSO ENDY- Bicho de luz, lampiris diáfana, Coleóptero.

YSO YVY - larvas de Coleóptero.

AMYNDAJÁI, YTAGUAPY - Insetos que vagam na água

TAPIRICHU - Pachymerus nuclearum. Bicho de coco e a larva deste Coleóptero.

MBUKU - Larva de Coleóptera.

Ordem Diptera - mberu no' $\tilde{o}$

$M B E R U$ - Moscas das frutas

Ordem Homoptera - Ñakyrã no' $\tilde{\boldsymbol{o}}$

$\tilde{N} A K Y R \tilde{A}$ - variedades de Cigarras.

TAMBEJU'A KA'AGUÝ - Gênero edesa.

Ordem Hymenoptera - Tahýi no' õ

TAHÝI - nome geral da formiga.

ARARA'A - Formiga negra, Camponatus senex mus.

YSAU - Formiga vermelha, grande. Atta sexdens L. attidio. É a cortadeira ou saúva.

AKEKE - Variedade de YSAÚ. Atta subterrânea. (quenquém).

TAHÝI- PYTÃ - formiga vermelha de diversas espécies.

TAHÝI PUKU; TAHÝI REVI PUKU. Ponera e paraponera e várias espécies.

TAHÝI VEVE - Isóptera e formigas aladas.

TAHYI JAGUAREVI - Camponotus cericentris, variedades de formigas.

KYVU KYVU - Formiga leão, que anda para trás.

Ordem Hymenoptera: Kava no'õ

KAVA, EIRARUA, EIRUSU - Apidae, variedades.

APYNGUAREÍ - Trigona; e variedades.

TAPESU'A- Trigona bipunctata.

EIRA APU'A - Trigona rufriens.

EIRA YVYGUY - Várias trigonas.

$S A \tilde{N} A R O$ - Nome comum para abelhas solitárias verdes e azuis. Andrenídae.

EIRUSU - Apis mellifera. 


\section{Ordem Isoptera - Kupi'i no' $\tilde{o}$}

KUPI'I - Termes alados, cupim.

TAKURU - Cada termiteiro em forma de montículo. Itacuru: itapecuim. KANGO - Soldados dos termes.

$A R Y R Y ́ I$ - Indivíduos alados dos termes. Ephemerid

\section{Ordem Lepidoptera - Panambi kure no' õ}

PANAMBI - variedades de Mariposas e borboletas.

TAMBU TERÃ MBUKU- Larva comestível de takuara: Morpheis smerintha; de pindo: Rhina barbirostris.

\section{Ordem Odonata - Ñahati no' $\tilde{\boldsymbol{o}}$}

NAHATĨ GUASU - Libélulas, libellulidae.

$\tilde{N} A H A T \tilde{I}$ - Libélula, lavadeira.

\section{Ordem Orthodoptera -Kyju no'̃}

KYJU - Grilos.

TUKU - Gafanhoto. Acriideos e tetticomideos.

TUKU, PYTÃ - Schiatoxerca paranensis. Acrídeo, (que aparecem em nuvens).

TUKU HOVY - Esperança. Elacochtora viridicata, tettigom.

Os insetos citados acima são úteis para seres humanos e meio ambiente. A expressão mais usada na língua Guarani é a expressão vicho'i iporãva ou mymba iporãva. Durante as entrevistas, os indígenas Guarani de Pirajuí descreveram sete espécies de insetos que são utilizados como alimento e como remédio. Dentre eles, cinco pertencem à ordem Coleóptera, um está na ordem Hymenóptera e outro na ordem Homóptera. Os insetos consumidos adultos pelos Ava Guarani de Pirajuí não pertencem à ordem Coleóptera.

Ysa (Ordem Hymenoptera: Attas sexdens) quer dizer parecido com olho d'água. O ysa também é consumido na comunidade no período de outubro a dezembro. Segundo os caciques entrevistados, o ysa sai uma vez por ano. Conhecido como ysau jarýi, quer dizer, as avós das formigas. Ysau jarýi possuem as seguintes cores: cor avermelhada e cor escura na região abdominal e vermelha na região dorsal (pytangy); voam e andam, aparecem entre os meses de outubro a dezembro. O Ysa é comido cru, moqueado, assado, frito e cozido.

Nakyrã kindi são espécies de cigarras (Ordem Homoptera: CicadidaeMagicicada sp) um pouco menor que as outras, aparecem anualmente, possuem cores variadas: olhos vermelhos, listras amareladas ou alaranjadas no lado de baixo do corpo do inseto, as asas são translúcidas e têm veias alaranjadas, voam. Geralmente descem nas pedras úmidas para se alimentarem. Apare- 
cem anualmente na primavera e no verão. As cigarras são reconhecidas pelos Guarani por seu canto, que é assim: kindi!kindi!kindi!kindi! Por isso o nome ñakyrã kindi. Essa cigarra verde clara era comum no período de verão, encontrada na beira de rio, repousando em cima das pedras. As cigarras podem ser consumidas cozidas, fritas e moqueadas. O consumo desse inseto, segundo os entrevistados, tornou-se raro, pois a extinção do mato ao redor da aldeia e o uso de inseticida em lavouras no entorno vêm extinguido essa espécie. Conforme Marshall e Cooley (2001), existem poucos estudos sobre as cigarras de espécies Magicicada, portanto, o assunto é pouco conhecido.

\section{Conhecimentos sobre as larvas comestíveis na aldeia Pirajuí}

As espécies comestíveis na língua Guarani são aramanday. Essa palavra quer dizer "o que cai como chuva". Ama significa chuva e nday significa com a chuva. A palavra ára quer dizer o dia e manday que significa o que cai com a chuva. O aramanday é o besouro que põe o mbuku. O mbuku é qualquer larva de inseto comestível. As demais larvas que não são comestíveis são chamadas de $y s o^{3}$. Portanto há outras espécies de besouros que não são comestíveis. Os Guarani Nandéva de Pirajuí utilizam como alimento e como remédio somente as larvas de besouros que infestam palmeiras e larvas de mariposa que infestam bambus. Além das larvas, os insetos adultos que são usados como alimentos na aldeia Pirajuí, são utilizados pelos nomes dados em Guarani, a cigarra na língua Guarani é o ñakyrã e formigas aladas o termo usado é ysa.

Tupã Guasu criou os aramanday guasu e aramanday mirĩ, no princípio da criação, para os Guarani Ñandéva se alimentarem. Segundo o cacique Carmelo Duran, de 87 anos, isso aconteceu quando o Tupã Guasu estava se preparando para ir embora dessa terra para Yvy Marae' $\tilde{y}$, daí ele preparou os alimentos necessários para o povo guarani. Tupã Guasu criou os animais e os colocou no lugar certo para que os animais também pudessem ter comida para se alimentar. Assim, ele criou as plantas frutíferas e não frutíferas. Ele criou as aves e também precisou colocá-las em vários locais, assim houve necessidade de ter árvores que produzissem pequenas frutas para alimentar as aves. Todos esses animais precisariam beber água, então, colocou água na face da terra.

O senhor Amalho Gonzales, de 89 anos, informou que o Tupã Guasu criou tudo. Ele mostrou para os Guarani Nandéva quais animais se podem comer e quais os que não se podem comer e nem tocar. Veja as expressões que o cacique utilizou na entrevista: "Nós podemos comer içás (ysa), cigarras (ñakyrã kindi), larvas de besouros (mbuku), peixes (pira). Esses animais não há restrições para comer; os adultos, velhos, crianças e jovens podem comer". Ele

\footnotetext{
${ }^{3}$ Significa corpo composto de água.
}

Tellus, ano 12, n. 23, jul./dez. 2012 
também afirmou que a "ordem do Tupã Guasu é que podemos comer insetos que possuem cores brancas, com cores esverdeadas e com cores avermelhadas". Os aramanday guasu e mirĩ possuem cores avermelhadas, portanto o Guarani local reconhece como inseto que pertence ao grupo comestível. Não se come o besouro adulto, apenas as larvas de aramanday.

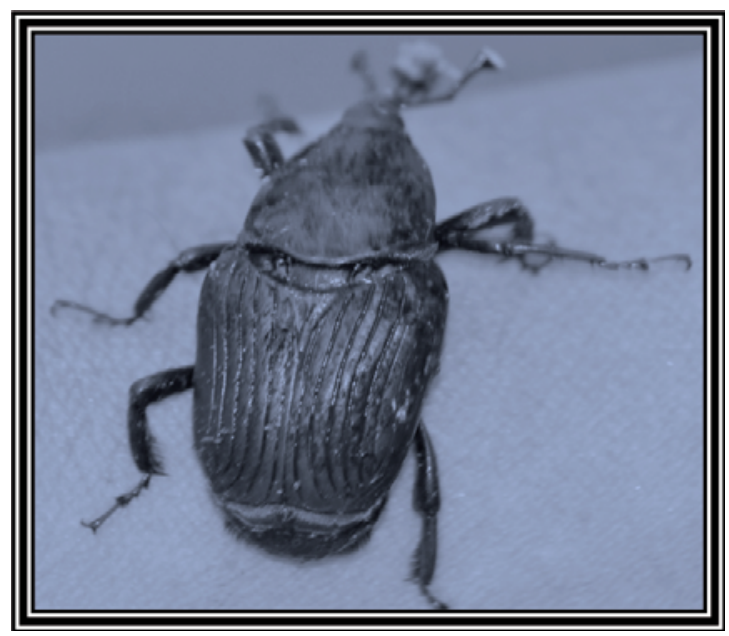

Figura 1 - Rhychophorus palmarum. Na língua guarani, aramanday guasu

Segundo os caciques dona Paula Cabral, de 109 anos; dona Gregoria Cabral, de 78 anos; Estanilao Vera, de 62 anos; Narciso Vera, de 52 anos; Pedro Duran, de 42 anos; Jonathas Duran, de 38 anos; e Lídio Vera, de 28 anos, o mbuku pode ser saboreado cozido, assado, frito ou cru. E, para usar como remédio, extrai-se o azeite da larva por meio de fritura e guarda-se em lugar seguro ou em vidro pequeno. O azeite das larvas de aramanday é usado para curar as seguintes doenças: doença de pele, como ressecamento de pele, doença provocada por fungos e doenças respiratórias como tosse, infecção de garganta etc.

Segundo Incekara e Türkez (2009) e Mitsuhashi (2010), a entomoterapia ou zooterapia é comum em várias culturas, em diversas partes do mundo. Em geral, é usada para curar alguns tipos de infecções. A pesquisa realizada por Costa Neto, Ramos-Elorduy e Pino (2006) registrou 82 tipos de insetos que são úteis no tratamento de diversos tipos de doenças. No Brasil, há registro de zooterapia relevante; isso abre novas perspectivas para valorizar o uso de insetos que até o momento eram considerados inúteis no tratamento de doenças. Para descobrir novos compostos de bioativos, são necessárias mais pesquisas. 
Antigamente, o Guarani, quando ia pescar, caçar, fazer mondéu ou monde e também para construir sua casa, cortava as palmeiras ou coqueiros. Os que sobravam eram deixados para criar o aramanday (Rynchophorus palmarum). O aramanday é encontrado no mbokaja (Acrocomio aculeta), pindó (Arecastrum romanzzofianum), jakarati'a (Jacaratia spinosa) e jata'i (Butia yatay). As larvas que são encontradas em takuapi (Merostachys clausenii) e takuara (Bambusa vulgaris) também são conhecidas como mbuku, apesar de ser de outras espécies de insetos.

Atualmente, para criar as larvas, há necessidade de cortar palmeira na lua nova, no início da primavera. Mas a maneira como ocorre o acompanhamento ainda é como ocorreu no passado. Os Guarani cortam as palmeiras e esperam 42 dias para realizar as coletas, quando o mbuku guasu ou mbuku miri já estão prontos para o consumo. Alguns entrevistados informaram que há necessidade de verificar semanalmente para ter a certeza se ocorreu a infestação. A coleta precisa acontecer antes de terminar as dez semanas, pois, se passar esse prazo, as larvas iniciam o estágio pupal e já não servem para comer.

Geralmente quem realiza as coletas são os homens, porém, em alguns casos, a mulher também coleta. Atualmente, na aldeia de Pirajuí, não existe lugar para caça, e pouquíssimas casas são feitas de madeira de palmeira, a maioria é de alvenaria, portanto não se usa tanto cortar essas madeiras.

As coletas de larvas de takuara e takuapi ocorrem de sete em sete anos. $\mathrm{O}$ amadurecimento de takuara e takuapi obedecendo a este ciclo. Por isso, as larvas nessas plantas se desenvolvem em cada sete anos. Os indígenas Guarani reconhecem o ciclo de amadurecimento do bambu e da taquara. Quando completam o ciclo, começam a florescer, do início de novembro a janeiro. As mariposas (Morpheis smerintha) aparecem para se alimentar de néctar e põem os ovos nos colmos de taquaras para se reproduzirem. Os indígenas Guarani de Pirajuí informaram que, no início do inverno, as frutas de taquara começam cair, e as plantas começam a ficar amareladas. Nesse período, as larvas já estão prontas para o consumo, então começa a coleta. Os depoimentos demonstraram que os aramanday de takuara e takuapi já não existem mais na aldeia Pirajuí. Alguns entrevistados informaram que ainda se encontra na região de Cerro Memby, no Paraguai.

O gênero Metamasius (Horn, 1873), no conhecimento do não indígena está associado a várias plantas hospedeiras como cana-de-açúcar, bromeliáceas, palmáceas, musáceas, entre outras (Mexón, 1999). Em Pirajuí, não há relatos de que o aramanday mirĩ (Metamasius sp) $)^{4}$, tenha atacado plantação

\footnotetext{
${ }^{4}$ Além desse besouro, são parte do grupo aramanday mirĩ kuéra os Cosmopolites sp.
} 
de cana-de-açúcar, banana ou outras plantas. Eles afirmam que os caciques reconhecem as plantas que são hospedeiras desses insetos, e na comunidade, até o momento, essa espécie não foi encontrada em outras plantas.

Para Amorozo (2002), os povos extrativistas contribuem para diminuir a quantidade de pragas, principalmente as que pertencem à ordem Coleóptera. O povo guarani é extrativista, pois eles aproveitam a madeira do coqueiro para construir suas casas, o palmito é utilizado na alimentação, como também as frutas e sementes dos coqueiros, portanto isso contribui para diminuir a quantidade pragas.

\section{Caracterização das larvas de aramanday}

O mbuku guasu é a larva que sai do ovo de aramanday guasu. Tem cor branca (morotĩete), não possui pés (nda'ipýri), a cabeça é meio avermelhada (akã pytã), possui mandíbula muito forte para comer o miolo do coqueiro (hãa mbarete) e é desprovida de pelos (iperõ).

As larvas de takuara e takuapi são totalmente brancas, também são reconhecidas como mbuku guasu. São parecidas com o yso karu (larva de Lepidoptera). Elas têm garras e andam igual à larva de mandrova (Lepidoptera). Essa larva se alimenta de líquido que fica no colmo de bambu.

O mbuku mirĩ é a larva que sai do ovo de aramanday mirĩ. Tem cor branca (morotĩeta), não possui pés (nda'ipýri), a cabeça é meio avermelhada (akã pytã), possui mandíbula muito forte para comer o miolo do coqueiro (hãi mbarete), desprovida de pelos (iperõ) e a larva não anda de um lugar para outro.

O Tupã Guasu ensinou aos caciques que essas larvas podem ser consumidas como alimento, pois ele próprio comeu quando esteve nessa terra. $\mathrm{O}$ Guarani de Pirajuí as reconhece como alimento, seguindo os passos do Tupã Guasu.

Tabus sobre o consumo das larvas de aramanday

Todos os entrevistados afirmaram que para os Guarani Nandéva o mbuku não oferece nenhum perigo, pois eles não se lembram de doenças provocadas pelo consumo como alimento e nem no uso como remédio. $\mathrm{O}$ mbuku é um vicho'i limpo, foi classificado por Tupã Guasu como alimento, forte, fácil de digestão, não possui sangue, alimento que está disponível na natureza. Segundo os caciques de Pirajuí, os alimentos que não possuem sangue são alimentos que não possuem restrições para o consumo.

Se for comer o mbuku cru, precisa consumir no local, na hora em que está sendo retirado. Se for transportar para casa, a dona da casa precisa lavar 
bem e cozinhar para comer. Em geral, ele é comido com os outros alimentos, tais como mandioca, com a comida feita de milho, cará, batata. Se por acaso sobrar e deixar para outro dia, é necessário fritar e guardar na própria banha e consumir logo.

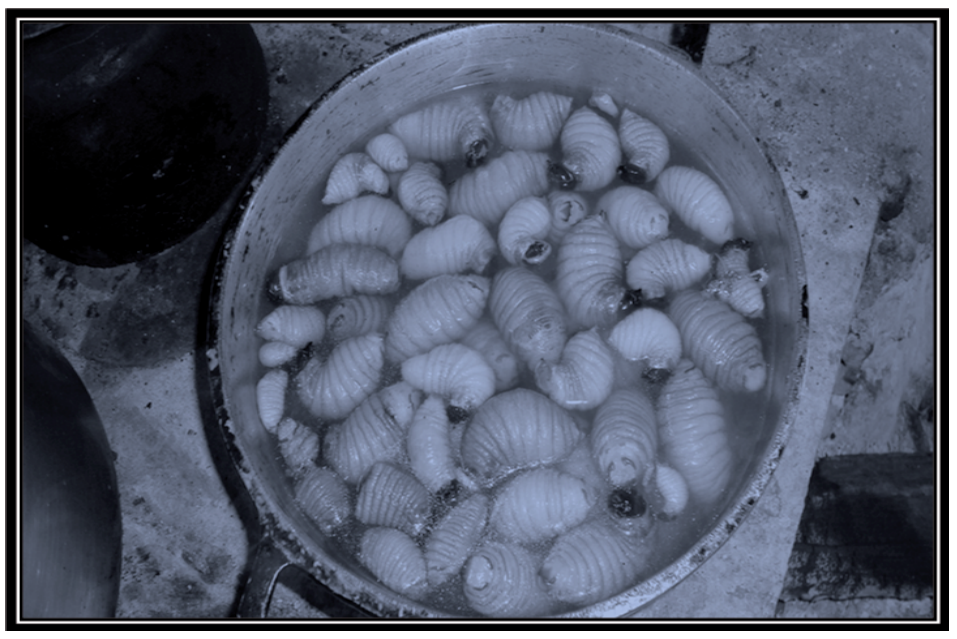

Figura 2 - Larvas de Rhynchophorus palmarum cozidas prontas para consumo. Na língua guarani, mbuku mimói

O uso de insetos como alimento, que é conhecido como antropoentomofagia (Ramos-Elorduy e Pino, 2011), ocorre naturalmente na aldeia Pirajuí e em outras localidades.

Segundo os caciques entrevistados, o perigo existe quando uma pessoa despreparada psicologicamente tenta comer, pois o Tupã Guasu deixou o mbuku para o Guarani Nandéva comer. O Guarani Ñandéva come na maior naturalidade, como se fosse comer picanha na cultura não indígena. Eles afirmam que se o não indígena ou o Guarani Kaiowá não come, não é porque não quer, é porque o Tupã Guasu não os preparou psicologicamente para isso, portanto eles têm muito medo do mbuku. Eles o enxergam como nojento, como algo feio, apavorante. Portanto seria difícil o consumo por quem não é Guarani Nandéva.

Essa barreira cultural e psicológica é extremamente importante para aprofundar o estudo sobre o alimento. Para Lima (2011), a maioria dos seres humanos não entomofágicos considera o consumo de insetos como prática de "gente primitiva". Segundo Canesqui (2005), o problema principal é que, por razões estéticas e psicológicas, muitos insetos são considerados animais nocivos, sujos, fora do padrão sanitário, portanto, transmissores de doenças e vistos como pragas. 
A repugnância pelo consumo de insetos, muitas vezes alimentada pela indústria de alimento, produção agropecuária e pelos comerciais de televisão que convidam ao uso indiscriminado de inseticidas, faz com que uma quantidade considerável de proteína animal se torne indisponível àquela parcela da população mundial que sofre com a fome e a desnutrição. O povo Guarani de Pirajuí detém os conhecimentos importantes sobre o consumo de larvas de aramanday, portanto é uma parcela pequena da sociedade que possui grande potencial para o desenvolvimento local.

Segundo os caciques e professores, os rituais de batismo dos jovens, o ñemongarai, são realizados para afirmar, diante da comunidade, que o índio guarani já é adulto. Esse ritual acontece quando os caciques acompanham a mãe, desde o início da gestação até o nascimento da criança. Na visão do guarani local, assim terão garantia de lares prósperos e abençoados por Tupã Guasu. Esses rituais não são realizados em Pirajuí desde 1996. Portanto, na comunidade já existem Guarani não entomofágicos. Estes enxergam as larvas de aramanday como algo nojento, nocivo, apavorante, pois, eles não receberam orientações dos pais e dos caciques e não estão preparados psicologicamente para comer as larvas. O senhor Celestino Benites, de 68 anos, afirma assim:

Às vezes, achamos que o costume do não indígena é melhor do que de nós indígenas, é verdade que há coisa boa no costume dele. Mas, como penso, se quisermos viver na cultura do não indígena, sofreremos mais, pois Deus nos fez indígenas, podemos aprender cultura não indígena e continuar do nosso jeito de ser. Mas, se deixarmos a nossa cultura, isso significa renúncia muito séria; do meu modo de pensar, nós vamos sair perdendo, nós indígenas temos opções para vivermos, mas o não indígena não tem. Aqui os professores ensinam às crianças o modo de ser do não indígena, há problemas dos lados, se aprendermos somente sobre a cultura do não indígena e deixar de aprender da nossa cultura. Por isso há crianças que não querem aprender nada sobre a nossa cultura. Assim estamos caminhando.

O senhor Celestino disse que na cultura não indígena há ensinamento muito válido, porém, para alcançar a igualdade entre o nosso conhecimento com o não indígena, paga-se um preço muito alto. E, até o momento, os mais jovens não conseguem perceber esse obstáculo, por isso os jovens estão valorizando mais o conhecimento do não indígena do que o próprio conhecimento de sua etnia.

\section{Restrições alimentares na aldeia Pirajuí}

Na cosmologia do Ava Guarani de Pirajuí, a escolha dos alimentos está ligada diretamente aos ensinamentos do Tupã Guasu. As meninas recebem as orientações a partir dos dez anos de idade e, quando iniciarem onze anos, elas 
não podem comer comida de origem animal, principalmente de mamíferos grandes que têm sangue. Os caciques entrevistados alegaram que essa restrição de alimentos para as meninas é para garantir a saúde da futura mãe, que precisa ser resguardada. Elas não podem comer carne de animais grandes até o batismo que coincide com a primeira menarca.

Após o batismo, as meninas já são adultas e podem se casar. As meninas, no período em que não podem comer carne que contém sangue, podem comer alguns tipos de carne que não tenha sangue: carne de peixes, alguns tipos de aves, larvas e bastante mel. E comida à base de milho, variedades de tubérculos, frutas e água. Portanto na visão do Guarani, com idade de 50 a 109 anos, poderiam ser chamados mais velho de Pirajuí; eles são fundamentais na vida de comunidade. A comunidade precisa valorizar os saberes desses caciques. Infelizmente os caciques afirmaram que o saber deles está sendo esquecido e que, por alguns motivos, a comunidade está generalizando com o conhecimento não indígena.

Segundo cacique Amalho Gonzales, de 89 anos, Tupã Guasu revelou para ele em sonhos os alimentos que precisam de alguns cuidados para comer, outros não possuem restrições e outras séries de alimentos não pode comer. Veja os depoimentos do cacique:

Existem comidas com restrições e devem ser obedecidos. Os alimentos que precisam ser abençoados ${ }^{5}$, principalmente, quando as crianças vão comer; são as carnes de animais grandes, estes animais têm sangues, Tupã Guasu, disse que animais com sangue podem trazer doenças. Por isso, não se pode comer crua, tem que cozinhar. As crianças, meninos e meninas, poderão comer carnes abençoadas até 11 anos, após completarem 11 anos, eles e elas passarão por batismos, então, poderão comer carne. O Tupã Guasu fez assim para que os jovens tenham saúde.

Os meninos e as meninas poderão comer carne de peixes, aves, frutas, larva, comida a base de milho e mandioca, ysa, ñakyrã, mel, chicha. Pois estas refeições não têm restrições por Tupã Guasu.

Eu sou um cacique, recebi revelações do Tupã Guasu, para orientar as pessoas para que eles possam viver bem. Eu também preciso obedecer à ordem do Tupã Guasu.

O cacique precisa estar pronto, dia a dia para realizar as atividades que cabem ao cacique. $\mathrm{O}$ cacique também não pode comer comida que o Tupã Guasu proibiu para comer. Até água é necessário usar com restrições, pois, na água tem que ter casca de cedro. Por isso precisa de vários caciques para cuidar do povo guarani.

\footnotetext{
${ }^{5}$ Benzido, na língua guarani diz-se jehovasa pyre.
} 
Comida que somente a senhora de idade pode comer são filhotes de animais recém-nascidos ou abatidos com os pais, miudezas de animais como fígado, rins, coração etc. Isso acontece não porque as pessoas de idade de 60 a 110 anos não possam comer qualquer comida, é porque muitas das pessoas com essas idades já não têm dentição e esse tipo de carne é mais fácil para cozinhar e preparar caldo para eles comerem.

Os alimentos sem restrições: as larvas de aramanday, içás, cigarra, mel, larvas de abelhas, ovos, peixes, aves. Estas comidas não têm restrições, podem comer qualquer pessoa. Somos descendentes diretos do Tupã Guasu, por isso ele deixou os alimentos e revelou para nós como usá-los.

Em Pirajuí, o uso de larva de aramanday é ligado às revelações do Tupã Guasu, em sonhos, aos caciques rezadores. Eles são responsáveis para repassar às revelações às crianças, principalmente para os meninos. A partir de quatro anos, eles receberão os ensinamentos dos pais e dos caciques; aprenderão habilidades para trabalhar na roça, caçar, construir casa etc. As meninas ficam na companhia da mãe e aprendem habilidades para cuidar da casa no dia a dia. As mulheres que foram entrevistadas disseram que já viram e que já comeram, mas, sempre afirmavam que os pais que traziam para casa, e a mãe que preparava as larvas para comer. Elas não possuem conhecimentos sofisticados como os homens sobre o aramanday. A mulher quando é cacique (xamã), nesse caso é diferente, ela recebe instrução do Tupã Guasu, então, ela passa conhecer tudo sobre o aramanday e sobre os demais insetos, pois, nesse caso, ela tem missão importante que é ensinar as crianças e jovens.

\section{Considerações finais}

Na aldeia Pirajuí (MS), os Guarani Nandéva ainda preservam tradições alimentares ligadas à cultura; possíveis de serem estudadas, documentadas e revitalizadas. Como exemplo disso, o costume de se alimentarem de insetos, dentre os quais as larvas mbuku. Os conhecimentos tradicionais; saberes transmitidos oralmente de geração a geração sobre os alimentos oriundos da natureza e as técnicas para obtê-los são cruciais para sobrevivência de muitos povos ao redor do mundo (Costa-Neto, 2003; Morris, 2008).

Diante das dificuldades de alimentação dos povos guarani na atualidade, vê-se a necessidade de descobrir e redescobrir alternativas de obtenção de recursos alimentares. Por isso essa pesquisa foi realizada entre os Guarani Ñandéva, retomando práticas alimentares inerentes à sua cultura, no caso o uso dos insetos na dieta, mais precisamente das larvas de besouros. Mesmo que os jovens do século XXI da aldeia Pirajuí demonstrem que não querem saber de consumir as larvas de aramanday, será muito mais fácil de reintroduzir 
o consumo nessa comunidade do que introduzir a entomofagia na sociedade brasileira ou na sociedade europeia.

Na visão do povo guarani, todos os animais têm dono (ijara), ou os animais pertencem a Tupã Guasu ou a Añay. Os alimentos bons para consumo, sejam eles de origem animal ou vegetal, foi o Tupã Guasu que criou e ensinou a usar. O conhecimento sobre o alimento para o povo guarani vem do Tupã Guasu e, este, em sonhos, revela aos xamãs ou caciques rezadores que, por sua vez, precisam repassar esses conhecimentos para os familiares. Os caciques reconhecem a importância do consumo de larvas de aramanday, por isso há necessidade de se detalhar esse conhecimento, para que possa fazer parte do saber ocidental.

O uso de aramanday na comunidade guarani é feito como comida e remédio. Como alimento na cosmovisão do Guarani, foi classificado com sendo alimento leve, sem restrições para consumo, quer dizer, este é um alimento para todas as idades. $\mathrm{O}$ alimento à base de larva de aramanday é considerado pelos caciques rezadores como alimento limpo, saudável, pois possui gordura que não faz mal à saúde. Por isso quando se alimentavam dele, os Guarani Nandéva eram sadios, fortes e tinham longevidade.

Agradecimento: Agradecemos a Nádia Heusi pelos comentários e sugestões à primeira versão deste artigo.

\section{Referências}

AMOROZO, Maria Christina. Agricultura tradicional, espaços de resistência e o prazer de plantar. In: ALBUQUERQUE, Ulysses P. et al. (Orgs.). Atualidades em etnobiologia e etnoecologia. Recife: SBEE, 2002. p. 123-131.

BADIE, Marilyn C. Espacio, Territorio y Resistencia Simbolica en los Mbya de Misiones, Argentina. In: CANAL, Gemma O.; LAVIÑA, Javier (comp.). Resistencia y Territorialidad: movimientos indígenas y afroamericanos. Barcelona: Universidad de Barcelona, 2008. (Serie Estudios de Antropología Social y Cultural 15).

BRAGA NETO, José Antônio; MORAES, Thays Silva; SKOWRONSKI, Leandro. Reflexões nutricionais sobre a alimentação dos índios Kaiowá e Guarani de Caarapó-MS: algumas preparações características. Tellus, ano 3, n. 5, p.107-120, out. 2003.

BRAND, Antonio J. O impacto da perda da terra sobre a tradição kaiowá/guarani: os difíceis caminhos da palavra. 1997. Tese (Doutorado em História) - Pontifícia Universidade Católica do Rio Grande do Sul, Porto Alegre, 1997.

CANESQUI, Ana Maria. Comentários sobre os estudos antropológicos da alimentação. In: CANESQUI, Ana Maria; GARCIA, Rosa W. D. (Orgs.). Antropologia e nutrição: um diálogo possível. Rio de Janeiro: Fiocruz, 2005. p. 255-289.

Tellus, ano 12, n. 23, jul./dez. 2012 
COIMBRA JÚNIOR, Carlos E.; SANTOS, Ricardo V. Avaliação do estado nutricional num contexto de mudança sócio-econômica: o grupo indígena Suruí do estado de Rondônia, Brasil. Cad. Saúde Pública, v. 7, p. 538-562, 1991.

COSTA NETO, Eraldo M. Etnoentomologia no povoado de Pedra Branca, município de Santa Terezinha, Bahia. 2003. Tese (Doutorado em Ecologia) - CCBS/Universidade Federal de São Carlos, São Carlos, SP, 2003.

COSTA NETO, Eraldo M.; RAMOS-ELORDUY, Julieta; PINO, Manuel J. Los insectos medicinales de Brasil: primeros resultados. Boletín Sociedad Entomológica Aragonesa, n. 38, p. 400-414, 2006.

CHAMORRO, Graciela. Terra madura: Yvy Araguyje. Fundamento da palavra Guarani. Dourados: UFGD, 2008.

CRISTANCHO-SÁNCHEZ, Sonia V.; BARRAGÁN-FONSECA, Karol B. Análisis del Sistema de aprovechamiento del gusano mojojoy (Rhynchophorus palmarum) (Coleoptera:Curculionidae) en el Municipio de Leticia, Amazonas, Colombia. In: MARTÍNEZ, Rafael M. et al. (Orgs.). Etnozoologia: un enfoque Binacional, MéxicoColombia. Centro de Investigaciones Biológicas. México: Universidad Autónoma del Estado de Morelos, 2011.

DIEGUES, Antonio Carlos; NOGARA, Paulo José. O nosso lugar virou parque. São Paulo: NUPAUB/USP, 2000.

FUNDAÇÃO NACIONAL DE SAÚDE - FUNASA. Funasa avalia mais de 1.800 crianças indígenas em uma semana. 2005. Disponível em: <http://www.funasa.gov.br/Web\%20 Funasa/not/not 2005/not057.htm>. Acesso em: 25 jan. 2008.

. Fundação Nacional de Saúde avalia situação de criança de Município de ParanhosMS. Funasa polo de Paranhos-MS. 2010. Disponível em: <http:/ / www.funasa. gov. br/Web\%20Funasa/not/not2005/not057.htm>. Acesso em: 25 jan. 2010.

. Relatório Anual de Nutrição e Dietética da Fundação Nacional de Saúde, 2009.

İNCEKARA, Ümit; TÜRKEZ, Hasan. The genotoxic effects of some edible insects on human whole blood cultures. Munis Entomology \& Zoology, v. 4, n. 2, p. 531-535, 2009.

JOÃO, Izaque. Jakaira reko nheypyru marangatu mborahéi: origem e fundamentos do canto ritual Jerosy Puku entre os Kaiowá de Panambi, Panambizinho e Sucuri'y, Mato Grosso do Sul. 2011. Dissertação (Mestrado em História) - Universidade Federal da Grande Dourados, Dourados, MS, 2011.

LIMA, Arthur G. D. Entomofagia e transmissão de doenças. COSTA NETO, Eraldo M. (Org.). Antroentomofagia: insetos na alimentação humana. Feira de Santana: UEFS Editora, 2011. p. 143-150.

MARQUES, Heitor R. et al. Metodologia da pesquisa e do trabalho científico. 3. ed. Campo Grande: UCDB, 2008.

MARSHALL, David C.; COOLEY, John R. Sexual signaling in periodical cicadas, Magicada sp. Behaviour, n. 138, p. 827-867, 2001. 
MELIÀ, Bartomeu. Elogio de la Lengua Guarani: Contexto para uma Educación Bilingue em el Paraguai. Asunción, Paraguay: Centro de Estudios Paraguayos "Antonio Guash", 1995.

MELIÀ, Bartomeu (Ed.). Guarani Retã: Povos Guarani na Fronteira Argentina, Brasil e Paraguai. [S.1.]: UNAM, ENDEPPA, CTI, CIMI, ISA, CAONAPI, SAI, GAT, SPSAJ, CAPI, 2008. p.7-16.

MELIÀ, Bartomeu; GRÜNBERG, Georg; GRÜNBERG, Friedl P. Los Pãi-Tavyterã Etnografia Guarani del Paraguay contemporáneo. Asunción, Paraguai: Centro de Estudios Antropologicos, Universidad Catolica “N.S. de la Asunción”, 1976.

Paĩ-Tavytera. Etnografia guarani del Paraguay contemporáneo. Asunción: CEADUC-CEPAG, 2008.

MEJÍA, Mario A. Métodos e instrumentos para la investigación etnoecologica participativa. Etnoecológica, v. 6, n. 8, p. 129-143, 2002.

MEXÓN, Cristiane M. Plano de gestão estratégica para combater brocas de canade-açúcar, período de 1990 a 1996. In: MEXÓN, Cristiane M. Embrapa solos. Rio de Janeiro: [s.n.], 1999.

MITSUHASHI, Jun. The future use of insects as human food. In: DURST, Patrick B. et al. Forest insects as food: humans bite back. RAP Publication 2010/02. Bangkok: FAO, 2010.

MORRIS, Brian. Insects as food among hunter-gatherers. Anthropology Today, v. 24, n. 1, p. 80-123, 2008.

MÜLLER, Franz. Etnografia de los Guarani del Alto Parana: a los 100 años de la obra apostólica de la Congregación de los Misioneros del verbo divino en la Argentina. Rosário: ROCA, 1989. p. 70-80.

NOELLI, Francisco S. Sem tekohá não há teko: em busca de um modelo entoarqueológico da aldeia e da subsistência Guarani e sua aplicação a uma área de domínio do Delta do Rio Jacuí/RS. 1993. Dissertação (Mestrado em Arqueologia) - Pontifícia Universidade Católica do Rio Grande do Sul, Porto Alegre, 1993.

PIRES, Valentim; MACIEL, Nely A. Mitos que Identificam o Povo Guarani e seu Reflexo nas Famílias da Aldeia Pirajuí. In: SEMINÁRIO POVOS INDÍGENAS E SUSTENTABILIDADE: SABERES TRADICIONAIS E FORMAÇÃO ACADÊMICA, 4. Anais... Campo Grande: UCDB, 2011. Disponível em: <http://neppi.org/ eventos/4sustentabilidade/cd.html>. Acesso em: 20 set. 2011.

POSEY, Darrel A. Indigenous Knowledge and Ethics: A Darrel Posey Reader. New York: Routledge, 2004. p. 12-55.

RAMOS-ELORDUY, Julieta; PINO MORENO, José Manuel. Alcance y significado del valor nutritivo de indectos comestibles de México. In: COSTA NETO, Eraldo M. (Org.). Antroentomofagia: insetos na alimentação humana. Feira de Santana: UEFS Editora, 2011. p.77-90. 
RODRIGUES, Arnaldo dos S. Etnoconhecimento sobre abelhas sem ferrão: saberes e práticas dos índios Guarani M'byá na mata atlântica. 2005. Dissertação (Mestrado em Ecologia de Agroecossistemas) - ESALQ-Universidade de São Paulo, Piracicaba, São Paulo, 2005.

SANTOS, Neusa Maria Miranda dos. Insetos comestíveis na alimentação humana: estratégia de sobrevivência e segurança alimentar. In: COSTA NETO, Eraldo M. (Org.). Antroentomofagia: insetos na alimentação humana. Feira de Santana: UEFS Editora, 2011. p.123-138.

SCHADEN, Egon. Aspectos fundamentais da cultura guarani. São Paulo: EDUSP, 1974. p.32-40.

SETZ, Freire Zulnara Eleonore. Ecologia alimentar em grupo indígena: comparação entre as aldeias Nambikuára de Floresta e de Cerrado. 1983. Dissertação (Mestrado em Ecologia) - Instituto de Biologia/Universidade de Campinas, Campinas, 1983.

SILVEIRA, Nádia Heusi. Imagens de abundancia e escassez: comida guarani e transformações na contemporaneidade. 2011. Tese (Doutorado em Antropologia Social) - PPGAS/Universidade Federal de Santa Catarina, Florianópolis, 2011.

VERA, Cajetano. Larvas de aramanday guasu -Rhynchophorus palmarum- Linnaeus, 1958 (coleóptera: curculionidae) como alimento tradicional entre os Guarani Nandéva, na aldeia Pirajuí, município de Paranhos, Mato Grosso do Sul: uma visão de segurança alimentar e sustentabilidade social. 2011. Dissertação (Mestrado em Desenvolvimento Local) Universidade Católica Dom Bosco, Campo Grande, MS, 2011.

Recebido em 3 de julho de 2012

Aprovado para publicação em 7 de agosto de 2012 